\title{
SCOPE OF ARTICLE 6 OF THE EUROPEAN CONVENTION ON HUMAN RIGHTS - CONTRIBUTION OF THE EUROPEAN COURT OF HUMAN RIGHTS PRACTICE ${ }^{1}$
}

\author{
Ivan ILIĆ \\ E-mail: ivan@prafak.ni.sc.rs \\ Assistant professor, Faculty of Law in Niš \\ Saša KNEŽEVIĆ \\ E-mail: knez@prafak.ni.sc.rs \\ Full professor, Faculty of Law in Niš
}

\begin{abstract}
Article 6 of the European Convention on Human Rights (ECHR) contains a series of guarantees that together represent the right to a fair trial. According to the ECHR case law Article 6 of the European Convention applies to proceedings concerning "civil rights and obligations", as well as to proceedings concerning the "criminal charge" (autonomous concepts from Courts practice). According to the linguistic interpretation of the Convention, as well as the earlier practice of the European Court, the guarantees of the right to a fair trial refer only to the accused in the criminal proceedings. However, under the influence of the tendency to protect the rights of the injured party in criminal proceedings, which was promoted by the Council of Europe, the practice of the Court, by applying the "convention as a living instrument" principle, extends the scope of the application of Article 6 to the injured party. The authors deal with a critical analysis of the relevant case law of the Court in this domain, as well as the implications to the national law on the position of the injured party in the criminal proceedings.
\end{abstract}

Key words: article 6, fair trial, injured party, criminal proceedings, ECHR, ECtHR

\footnotetext{
${ }^{1}$ The paper was created as a result of funding by the Ministry of Education, Science and Technological Development of the RS according to the contract registration number 451-03-68 / 2020-14 / 200120.
} 


\section{Introduction}

It is known that criminal procedure is a human rights barometer in the country. Naturally, the defendant is in the most difficult position, because he usually suffers the restriction of human rights during the procedure. However, over time, it became clear that the injured party also needed protection during the procedure. The European Convention guarantees the right to a fair trial to the accused under Article 6. However, the European Court of Human Rights, as an authentic interpreter of the Convention, contributed by interpreting paragraph 1 of Article 6 of the Convention in its practice by extending certain guarantees to the injured party. The case law of the Court is very important for national legislations, so domestic courts should consider the protection of the human rights of the injured party. The aim of this paper is to point out the achieved standards of the Court in terms of protection of the injured party and the implications for domestic jurisprudence.

\section{The right to a fair trial - guarantees from Article 6 of the Convention}

Respect for basic human rights is a mirror of a democratic society. It is especially important to ensure their respect during court proceedings, ie. when an individual interacts with the state, embodied in the form of the bodies responsible for ensuring compliance with the requirements by which it regulates the behavior of individuals. The treatment of the accused during the criminal proceedings is of special importance. It is then necessary to balance ius puniendi with the rights of a potential perpetrator. If we add to that the request for efficient termination of the criminal procedure, in order to remove the state of uncertainty for the defendant, it is clear that what constitutes the phrase "fair trial" is not an easy task. This requirement undoubtedly contributes to the rule of law, legal certainty and, above all, justice. All this is reflected in the trust of citizens in the judiciary, for the state it means greater credibility before the international community. The set of the most important standards in court proceedings is the right (principle) of fair trial, which gradually grows into the central (super) principle of modern legal procedure (Krapac, D, 2000, p. 83, Đurđić, V, 2014, p. 53,55, Knežević, 2017, p. 46, Carić, M, 2006, p. 71, Mrčela, M, Bilušić, I, 2016, p. 371, Ilić, I, 2012, p. 211-212).

The set of rights that make up a fair trial is enshrined in the most important international human rights instruments. It is contained first in Article 10 of the Universal Declaration of Human Rights, then in the International Covenant on Civil and Political Rights, and finally in Article 6 of the European Convention for the Protection of Human Rights and Fundamental Freedoms, which provides that "In the determination of his civil rights and obligations or of any criminal charge against him, everyone is entitled to a fair and public hearing within a reasonable time by an independent and impartial tribunal established by law". 


\section{Limits on the application of Article 6 of the Convention}

The right to a fair trial affirms the rule of law and the principle of legal certainty. The guarantees referred to in paragraph 1 of Article 6 relate to proceedings concerning criminal charges, as well as to proceedings concerning civil rights and obligations. Paragraphs 2 and 3 of Article 6 of the Convention apply only to proceedings in which the merits of a criminal charge are decided. The Court assesses that this is a procedure in which a decision is made on a "civil right or obligation" or a "criminal charge" by interpreting these terms autonomously. In its jurisprudence, the Court has developed criteria for assessing whether it is a "civil right or an obligation" (Ringeisen v. Austria, § 94). The first criterion is actually the determination of the legal nature, whether it is a civil right or an obligation (Lič F, p. 245). That right, or obligation, must have a basis in domestic law (Benthem v. the Netherlands, § 32,36). Then there needs to be a dispute over that right, or obligation. Finally, it is necessary to have a decision on that dispute. The Court requests that the outcome of the proceedings before the national authorities be directly related to the law in question, and that the far-reaching consequences are not sufficient for Article 6 of the Convention to apply (Balmer-Schafrothi and Others v. Switzerland, §32, Le Compte, Van Leuven and De Meyere v. Belgium, § 47, Fayed v. the United Kingdom, § 56, Masson and Van Zon v. the Netherlands, § 44 ). On the other hand, the Court has established the criteria for testing whether a proceeding falls within a "criminal charge" and whether the guarantees of Article 6 of the Convention can be applied. These are the criteria established on the basis of the precedent in the case of Engel and Others v. The Netherlands. The first criterion of the three-part test is the qualification of illegal behavior in domestic law. It is not necessary that this is a criminal act, but that the goal of the state is to prevent and suppress illegal behavior. When illegal behavior is not defined as a criminal offense, then the second and third criteria are passed (Weber v. Switzerland, § 32-34). Another criterion for assessing the applicability of Article 6 is the legal nature of the act. Whether a certain unlawful conduct is considered a "criminal offense" is assessed by the Court from the aspect of domestic law, by comparison with other criminal offenses, within a specific legal system (Engel and others v. the Netherlands, §80-85). The third criterion is particularly pronounced in the case when after a cumulative application of the first and second criteria, it cannot be concluded that the case concerns a "criminal charge" (Ezeh and Connors v. the United Kingdom, § 108-130). In that case, the nature and severity of the punishment are assessed, where threatened, not imposed, sanction is assessed. Sanction should be repressive, not just preventive. Accordingly, the Court has developed a comprehensive test, as to whether the guarantees under Article 6 apply to the proceedings, in the present case. It is a question of the applicability of the Convention ratione materiae.

In addition to the substantive applicability, the case-law of the Court has provided an interpretation of the application of Article 6 of the Convention 
ratione personae. In that case, one must answer the question, as to which persons Article 6 applies. First of all, from the linguistic interpretation of the provision from paragraph 1 of Article 6, it can be concluded that it applies to decisions concerning civil rights and obligations, or a criminal charge. In the criminal procedure, it is decided on the basis of the criminal charge of the accused. Accordingly, the guarantees set out in paragraph 1 of Article 1 of the Convention apply to the accused. The defendant has the right to a fair and public hearing before an independent and impartial tribunal, which is constituted by law, within a reasonable time. The defendant has the right to a public pronouncement of the verdict, but the public may be excluded, in certain cases. The set of guarantees from paragraph 1 is indeed addressed to the accused, but when it comes to the publicity of the main trial and the presence of the public during the pronouncement of the verdict, the control the work of the judiciary needs to be taken into account, so that the addressees of the principles of publicity are set much more broadly. Paragraph 2, which prescribes the presumption of innocence, and paragraph 3 , which guarantees minimum rights of defense, are undoubtedly addressed to the defendant. This is explicitly stated, with paragraphs 2 and 3 of Article 6 refering to "everyone who is accused of a criminal offense". However, let us take two steps back. Apart from the defendant, the guarantees referred to in paragraph 1 of Article 6 also apply to "anyone" whose civil rights and obligations are decided before the Court. Is it about decisionof someone else's rights in the criminal procedure, except for the rights of the accused? In criminal proceedings, in addition to the main subject (criminal matter), certain secondary subjects are also decided. These are prejudicial issues, the costs of criminal proceedings and, most importantly for this topic - the property law claim. The injured party has the right to point out a property law claim in criminal proceedings, which may consist, as a rule, in compensation for damages, but also in returning things, or annulling a legal transaction (Knežević, 2015, p. 195).

The regular legal procedure to realizing a property claim of the injured party is litigation, but in many legal systems this right is also allowed in criminal proceedings. In the event that the injured party in the criminal procedure points out a property claim, during the procedure it is decided on his right to compensation for damage, return of property, or annulment of the legal transaction. In a broader sense, it is decided concerning the civil right of the injured party to compensation. In that case, a dilemma arises as to whether the guarantees from Article 6 of the Convention also apply to the injured parties, since in that case it is decided concerning their rights in criminal proceedings. The second question is whether the prescribed guarantees from Article 6 of the Convention apply to the injured parties, in case they appear in criminal proceedings without stating a property claim. In fact, there are two procedural roles. On the one hand, there are the injured parties, who appear in the criminal proceedings in the role of a party. This is possible, in the case of the withdrawal of the public prosecutor from the criminal prosecution, when the injured party can take over the criminal prosecution and when it comes to criminal offenses for which criminal prosecution is undertaken on the basis of a private lawsuit. 
In addition to the role of a party, victims in criminal proceedings may appear in the role of participants in the proceedings. In addition, it should be added the procedural position of the injured party which joins the criminal prosecution, which exists in some criminal proceedings, for example, in France. In all these procedural roles, the injured parties can participate in the criminal proceedings, without emphasizing the property claim. From the aspect of application of guarantees from Article 6 of the Convention, it is important to point out the fact that in these cases it is not the case of deciding about the civil rights or the obligations of the injured party during the criminal proceedings, given that the right to punishment (ius puniendi) belongs to the State. The injured party only has a legal interest of the defendant being sanctioned for committing a crime. The right to punishment is not transferred to the injured party even in the case of criminal prosecution on a private lawsuit. Rather, in criminal acts, for which the state assesed that their execution dominantly violated or endangered the private interests, the criminal lawsuit is left to the injured party. Therefore, even in criminal prosecution on a private lawsuit, during the criminal procedure, it is not decided on the right of the injured party, but on his request, articulated in the private lawsuit, to impose a criminal sanction on the defendant, if it is determined with certainty that defendant committed a crime.

The question of the applicability of the guarantees under Article 6 of the Convention has also been addressed by the Court in its case-law, in an attempt to answer the question whether these guarantees apply to the injured party. In that case, the principle, which was established in the Courts practice, that the Convention is the so-called "living instrument", which is interpreted in accordance with current social circumstances, come to the fore (Tyrer v. the United Kingdom, §31).

In the last three decades, the Council of Europe has adopted several documents, which deal with the position of the victim in criminal proceedings. First, the Resolution on Compensation of Victims of Crime was passed, in 1977. After that, in 1983, the European Convention on the Compensation of Victims of Violent Crimes was adopted. This Convention affects the improvement of the situation of victims of criminal offenses in criminal proceedings by requiring States Parties to establish a special program to cover the costs of treatment of bodily injuries or ill health, funeral expenses and loss of subsistence, and recovery from victimization (Article 4). After that, several recommendations were made regarding the status of the victim in criminal proceedings. The first of them is the Recommendation on the position of the victim in the framework of criminal law and procedure. One of the objectives of the adoption of this Recommendation is to take into account the needs of victims to a greater extent during all stages of criminal proceedings. The recommendation stipulates that the police should have special training for dealing with victims as well as an obligation for the police to inform the victim of their rights in the proceedings. The prosecution is required to inform the injured party of the decision not to prosecute and that the injured party should have the right to appeal the public prosecutor's decision not to prosecute. The rules for examining the injured during the procedure are also stated, with 
respect for their dignity. Finally, compensation for damages is envisaged, as well as protection of the victims from harassment.

The Recommendation on the assistance to victims and the prevention of victimization provides for different models, types and programs of assistance and support to victims during criminal proceedings, while respecting the right to defense of accused. All envisaged measures are aimed at reducing the consequences of primary, and preventing the occurrence of secondary victimization. Special emphasis is placed on respecting the needs of particularly vulnerable categories of victims. This recommendation has been replaced by the 2006 Recommendation of the Committee of Ministers of the Council of Europe on Support to Victims of Crime. The new recommendation provided more comprehensive programs and modalities for victim support and assistance. Special emphasis is placed on informing victims about the rights they have during the criminal proceedings, especially concerning the fate of the criminal report, and the course and outcome of the criminal proceedings. The right of the injured party to instruction and support regarding the realization of a property claim in criminal proceedings is also envisaged. The Recommendation on the Role of the Public Prosecutor in the Criminal Justice System is also important for the rights of victims in criminal proceedings. This recommendation insists on the obligation of the public prosecutor to consider the rights of victims and to adequately inform them about these rights, at the stage of the procedure, where public prosecutor is dominus litis. The right of the injured party to challenge the decision of the public prosecutor to undertake criminal prosecution is especially emphasized.

\section{Previous approach to the Court's case law}

In previous practice, the European Court of Human Rights has applied a narrower interpretation of the scope of application of Article 6, when it comes to the application of guarantees from that Article to the injured party in criminal proceedings. This older concept was based on an assessment of whether there was a "dispute" between the parties in a particular case, in terms of "civil right or obligation".

The case of Moreira de Azevedo v. Portugal, was the first decided by the Commission, which ruled that there was no place for the application of Article 6 of the Convention. The court, however, made a different decision, in relation to the Commission. The applicant participated in the criminal proceedings as an assistant to the public prosecutor. This is a possibility, which is provided for in the Portuguese procedural law, and elaborated in more detail by Regulation no. 35007. The injured party in the criminal proceedings of Portugal may participate in the criminal proceedings in the capacity to the assistant of public prosecutor. In that case, he has the right to propose evidence during the procedure, to file complaints and has the right to appeal against decisions during and after the procedure (Moreira de Azevedo v. Portugal, $\S \S$ 51-52). The injured party, according to Article 28 of the Criminal Procedure 
Code of Portugal, may file a claim for damages. The applicant did not explicitly make such a request during the proceedings. Rather at the beginning of the main trial his attorney requested that the determination of the amount of compensation for damages be postponed until the beginning of the enforcement procedure.

The applicant claimed that there had been a violation of Article $6 \S 1$ of the Convention on account of the violation of his right to a trial within a reasonable time. The Commission found that there was no place for the application of Article 6 of the Convention, as the applicant had not submitted a claim for damages in the criminal proceedings. The Commission has taken the view that the guarantees provided for in Article 6 of the Convention cannot be applied, whether or not the Court awarded a certain amount to the injured party in the name of damages, because the applicant did not request the determination of his right during the proceedings (Moreira de Azevedo v. Portugal, §§ 65). The Court emphasized the importance of the right to a fair trial in a democratic society, and that consequently it could not be interpreted restrictively. The Court also underlines that the autonomous term "dispute" must be given a substantive rather than a technical meaning. The key argument for the Court's conclusion that Article $6 \S 1$ of the Convention may be applied to the injured party in the present case is the fact that the applicant, by joining the prosecution as an assistant public prosecutor, expressed an intention to establish a pecuniary reparation (Moreira de Azevedo v. Portugal, $\$ \S 66-68$ ). The Court, however, mentioned another criterion, that the result of the criminal proceedings is of crucial importance for the exercise of rights (Moreira de Azevedo v. Portugal, $\S \S 66)$, which, however, when applying the general principles to the facts of the specific case, did not apply.

The Court applied the established criterion in a decision made two years later in the case of Tomasi v. France. The Government raised the objection of the inapplicability of Article 6 of the Convention, arguing that the victim's association with the prosecution did not constitute a "determination of civil rights and obligations", but the victim's desire to be convicted of the crime (Tomasi v. France, $\S 120$ ). Unlike the Moreira de Azevedo case, here the Commission and the Court agreed that Article 6 was applicable. The Court cited Article 85 of the French Code of Criminal Procedure, which is the legal basis for a victim's association with criminal prosecution. The investigating judge accepts the request of the injured party to join the criminal prosecution if it is determined that there is damage and a direct connection between the damage and the crime. Therefore, the right to compensation directly depends on the outcome of the criminal proceedings. The court concluded that this is a civil right of the injured party, regardless of the fact that the criminal court is entrusted with deciding on that.

In the case of Acquaviva v. France, the Court found the existence of a "dispute", as to civil right or obligation, as a key criterion for the applicability of Article 6. That dispute must be qualified, more precisely genuine and serious, and it should refer not only to the existence of the right, but also to its scope 
and the manner of its realization. However, in the Acquaviva case, the Court introduced another (otherwise previously known) criterion for the application of Article 6 of the Convention (Le Compte, Van Leuven and de Meyer v. Belgium). The Court considered that the outcome of the proceedings should be directly decisive for the right in question (Acquaviva v. France, § 46). Applying the above criterion, the Court concluded that Article 6 of the Convention is applicable in the present case, as the applicants initiated their own participation in the proceedings, granted by the court, precisely in order to claim damages on the basis of the judgment. As the national appellate court handed down a verdict of acquittal, this deprived the applicants of any possibility to claim and obtain compensation in criminal or civil proceedings. The Court therefore concluded that the outcome of the criminal proceedings before the national courts was decisive for the applicant's rights (Acquaviva $\mathrm{v}$. France, § 47).

The Court reiterated the above criteria from the Acquaviva judgment in Hamer v. France. In that case, the sister of the deceased joined the criminal prosecution during the criminal proceedings, in the capacity of a civil party. She did not explicitly point out the claim for damages during the criminal proceedings. The Commission's position was that, notwithstanding the absence of a claim for damages, the mere joining of a prosecution constituted a manifestation of such a claim, and established the applicability of Article 6 of the Convention. The Court, however, took a different view from the Commission and ruled that Article 6 of the Convention was not applicable in the present case. In the reasoning of the decision, the Court pointed out as key arguments that the applicant did not file a claim for damages during the criminal proceedings, nor at the investigation stage, nor later, during the trial, nor did she initiate litigation after the criminal proceedings, to that end. Comparing the above case with the cases of Tomasi and Acquaviva, the Court pointed out that there is a key difference, because in this case the main trial was conducted, while in the other two cases it was not, and in the case of Acquaviva the applicant was prevented from obtaining damages by the decision of the appellate court that it was a matter of self- defense. The Court therefore concluded that in the Hamer case the outcome of the proceedings was not decisive for the exercise of the right to compensation, and that there was no "dispute" over that right.

The Court also applied the criteria of the existence of a "dispute" and the decisive outcome of the dispute to the applicant in the case of Ait-mouhoub v. France. In the present case the applicant alleged a violation of Article 6 of the Convention, arguing that he had not been allowed to access to a court due to the excessive costs of the proceedings. The Court found that Article 6 of the Convention was applicable in the present case, citing as a key argument that the applicant had explicitly stated in one of the lawsuits that he had suffered a financial loss as a result of the theft. The Court considers it irrelevant that the applicant did not quantify the amount of damage he suffered, as he could have determined his claim later, during the proceedings (Ait-Mouhoub v. France, $\S$ 44). Similarly, in Maini v. France, the Court found the applicability of Article 
6 of the Convention, given that the applicant had alleged in his criminal complaint that he had suffered material and moral damage as a result of the offenses with which he had been harmed. As in the case of Ait-mouhoub, the Court considered it irrelevant that the property claim was not determined by the amount, given the possibility to do so during the criminal proceedings. Given that the criminal proceedings were terminated, the applicant had no chance of success in the litigation, on the basis of which the Court concludes that the outcome of the proceedings had a decisive influence on the applicant's right to compensation (Maini v. France, §28-30).

\section{New criteria and new court practice}

In its case law, which is based on a case by case approach, the European Court of Human Rights in some similar cases changed its position on certain issues. This is exactly what happened in the case of the question of the scope of application of Article 6 of the Convention to the injured party in the criminal proceedings. The turning point, which changed the course of the Court's practice, was Perez v. France. The applicant tried to prove before the national authorities that she had been harmed by being physically assaulted by her two children, during which she had been injected with an unknown liquid. She lodged a criminal complaint, on the basis of which an investigation was launched, during which the applicant joined the prosecution, as a civil party. The investigation was suspended by the investigating judge, due to lack of evidence. The applicant lodged an appeal against this decision, which was dismissed as inadmissible. The applicant submitted a request for revision of that decision, which was rejected. In that way, the applicant exhausted domestic remedies. She lodged a complaint with the Court alleging a violation of Article 6 of the Convention.

The Court begins its finding with a summary of past practice, analyzing the Court's decisions in the Tomasi, Acquaviva, Hamer, Aït-Mouhoub and Maini cases, setting out the established criteria for assessing the applicability of Article 6 of the Convention to the injured party during criminal proceedings. The Court states that the criteria, which have been applied in practice, after the Tomasi case set certain limits for resolving this issue. The judges of the Grand Chamber considered that determining the existence of a "dispute" over the existence of civil law and the decisive influence of the outcome of the proceedings on the applicant complicated court decisions and affected legal certainty in resolving the application of Article 6 of the Convention. The Grand Chamber considered it difficult to establish the existence of a criterion of decisive influence, especially in a situation where the proceedings at national level had not yet been completed, as the court should prejudge the outcome of the applicants' future appeals (Perez v. France, $\S 55$ ). The Court therefore emphasizes its intention to end the uncertainty as to the applicability of Article 6 of the Convention to the injured party in criminal proceedings, as there is a similar model of participation of the injured party in this type of procedure in other European countries. 
In the Perez case, the Court promotes a new approach to resolving the issue of the application of Article 6 of the Convention. The Court starts from the premise that the nature of a "civil right or obligation" is determined on the basis of national law. The court determines the criteria for that classification. Apart from the legal nature, the decisive factor is the material content of the subject law and the effect at the national level (Perez v. France, § 57). The court analyzed the French legislation, which gives the injured party two possibilities - participation in criminal proceedings, or initiating litigation. French law favors criminal proceedings, providing that compensation in litigation depends on the outcome of the criminal proceedings and that the criminal judgment takes precedence over the judgment in the litigation. The injured party, if he opts for criminal proceedings, can initiate this by filing a criminal complaint, or he can join the criminal prosecution by giving a statement to the investigating judge or the trial court. The injured party thus has certain rights in criminal proceedings, to be informed about the course of the proceedings, to review the case file, to submit requests, to appeal the verdict and finally to compensation. Based on the analysis of the national legislation, the Court concludes that the participation of the injured party in the criminal proceedings is, by its legal nature, undoubtedly a civil action for damages. The court is explicit regarding the formal presentation of the claim for damages during the criminal proceedings and points out that the "dispute" over civil law does not start the moment that the injured party points out the property claim. It is sufficient that the outcome of the proceedings has a decisive influence on the exercise of the injured party's right to compensation. In the context of French law, that moment is the point of joining the criminal prosecution, ie during the investigation, initiated by the criminal report of the injured party, regardless of when and whether he pointed out the request for compensation. This is valid even if a civil procedure is in progress, or is possible, because according to French regulations, criminal procedure has precedence over litigation.

It is this second criterion of "decisive influence on the outcome of the proceedings" that has been revised and modified in the Perez case. Namely, the Court points out that even when the outcome of the criminal proceedings is decisive only for the merits of the criminal charge and not for the injured party's right to compensation, the applicability of Article 6 of the Convention depends on the impact of the criminal proceedings on the civil component, from the inclusion of the injured party in the proceedings to the end of the criminal proceedings. The Court therefore establishes a new criterion - the close links between the civil and criminal components and applies it to the example of French law. The court points out that criminal proceedings at the request of the injured party in France automatically lead to criminal prosecution. This fact does not deprive the procedure of a civil character, because the public prosecutor and the injured party are two independent procedural subjects, which are not opposed, nor are they both parties. The Court concludes that there is a clear distinction and separation between the formality of the prosecution and the injured party's right to a private action in French criminal proceedings. 
In conclusion, the Court sets limits on the applicability of Article 6 of the Convention. The application of this article is valid to the extent of the injured party's right to institute criminal proceedings under national law, even if only in order to ensure symbolic compensation, or to protect the right to a good reputation (Perez v. France, $\S 70$ ). In other words, Article $6 \S 1$ of the Convention cannot be applied if the injured party seeks private revenge as a result of the criminal proceedings, or if he files an actio popularis. Lastly, the Court points out that the failure to apply Article $6 \S 1$ of the Convention must be exercised restrictively in order to protect the rights of victims of criminal proceedings and ruled that, in the present case, the guarantees provided for in Article $6 \S 1$ of the Convention were applicable, and rejected the Government's request that the application be declared inadmissible ratione materiae.

The Court's new approach to the applicability of Article 6 of the Convention is in fact sublimation and rounding of the standard, which has already been applied in its jurisprudence. This is the case of Calvelli and Ciglio v. Italy (judgment delivered in 2002, two years before the Perez judgment), in which the applicants were the parents of a newborn child, who died two days after birth as a result of reckless homicide by a doctor. They filed a criminal complaint against the doctor, on the basis of which criminal proceedings were initiated and conducted, in which they participated as injured parties. In the repeated procedure, after the conviction against the doctor, the procedure was suspended due to obsolescence. The applicants then brought a lawsuit against the doctor, in which they settled with the insurance company for damages. They subsequently applied to the Court, inter alia, for alleged violation of Article 6 of the Convention, specifically alleging a violation of the right to a trial within a reasonable time, due to the excessive length of the criminal proceedings. The Court joined the decision on the applicability of Article 6 of the Convention to the decision on the merits and pointed out that it was indisputable that the result of the criminal proceedings affected the applicants' claims, submitted as injured parties, although the criminal proceedings concerned the determination of the doctor's guilt. The Court underlines as a key criterion for deciding on the applicability of Article 6 of the Convention that the civil and criminal components of the proceedings were closely linked from the moment the applicants joined the prosecution to the end of the criminal proceedings (Calvelli and Ciglio v. Italy, § 62).

\section{National regulations}

According to the Code of Criminal Procedure (CPC, "Official Gazette of RS", no. 72/2011, 101/2011, 121/2012, 32/2013, 45/2013, 55/2014 and $35 / 2019$ ), injured parties may file a property claim, the subject of which is usually compensation, ${ }^{2}$ during criminal proceedings (Article 50, paragraph 1, item 1 of the $\mathrm{CPC}$ ). The injured party can exercise this right from the beginning

\footnotetext{
${ }^{2}$ In addition to compensation for damages, the subject of a property claim can also be the annulment of a legal transaction and the return of property.
} 
of the investigation. Unlike in France, where the investigation is entrusted to an investigating judge, in Serbia the head of the investigation is the public prosecutor. Also, the injured party can initiate criminal proceedings by filing a criminal complaint. Unlike the French criminal procedure, the injured party does not join the criminal prosecution of the public prosecutor, but can participate in the procedure with or without a property claim. In addition, the injured party may take over the criminal prosecution in the event that the public prosecutor withdraws from the criminal prosecution, from the confirmation of the indictment, to the end of the main trial. In that case, the injured party becomes a party to the criminal proceedings, representing the prosecution. Finally, for a number of criminal offenses, for which the legislature estimated that their commission violated mostly private interests, the criminal prosecution was left to the injured party acting as a private prosecutor.

In all procedural roles, in which the injured party may find himself in criminal proceedings, he may point out a property claim. According to the provisions of the procedural law, a property claim may be submitted by a person who is authorized to initiate litigation, ${ }^{3}$ regarding the damage caused by the commission of a criminal offense. If he did not do so in the previous procedure, the injured party may do so at the preparatory hearing (Article 348, paragraph 4 of the CPC). If the injured party is not present at the preparatory hearing, the president of the panel may read the previously submitted property claim (Article 349, paragraph 2 of the CPC). At the main trial, the injured party may file a property claim after presentation of the indictment (Article 391, paragraph 2 of the CPC). The injured party may also explain the property claim after the introductory statements of the parties (Article 393, paragraph 4 of the CPC). A property claim may be filed no later than the end of the main trial before the court of first instance (Article 254, paragraph 2 of the CPC). The court will decide on the property claim if it does not significantly delay the criminal proceedings (Article 252, paragraph 1 of the $\mathrm{CPC}$ ). The decision on the property claim can be threefold. If the request was submitted by an unauthorized person, the court will reject it. Otherwise, the request may be accepted in part or in full, in the case of a conviction (Article 258, paragraph 4 of the CPC). This decision will be made only if the evidence collected in the procedure provides a sufficient basis for making a decision on the request. Otherwise, the court will refer the injured party to a lawsuit to settle the property claim. If the court renders a verdict of acquittal, a verdict rejecting the accusation, or if the proceedings are suspended, it will certainly refer the injured party to litigation for the realization of that request (Article 258, paragraph 3 of the CPC).

Another legal way to exercise the right of the injured party to compensation for damage caused by the commission of a criminal offense is

\footnotetext{
${ }^{3}$ According to Article 74, paragraph of the Law on Civil Procedure ("Official Gazette of RS", No. 72/2011, 49/2013 - decision of the CC, 74/2013 - decision of the CC, 55/2014, 87/2018 and 18/2020) is prescribed that a party to civil proceedings may be any natural or legal person.
} 
civil proceedings. In that case, compensation for damage occurs on the basis of the Law on Obligations (Official Gazette of SFRY, no. 29/78, 39/85, 45/89 decision of the USJ and 57/89, Official Gazette of the FRY, no. 31/93 and the Official Gazette of Serbia and Montenegro, no. 1/2003) to whom the person who suffered damage has the right to compensation, ie the right to restitution and the right to compensation for damage in money. The Law on Civil Procedure (LCP) does not explicitly prescribe the priority of criminal proceedings over civil proceedings. Article 13 of the LCP stipulates that the civil court is bound by the final conviction of the criminal court, in terms of the existence of a criminal offense and criminal responsibility. Therefore, this is a preliminary issue for the civil court, as a result of which, as a rule, it terminates the civil proceedings until the final conclusion of the criminal proceedings. A verdict of acquittal in criminal proceedings does not necessarily mean the absence of the possibility of compensation in litigation, given that the principles of determining responsibility in criminal and civil proceedings are not the same. Therefore, there is a legal possibility for the injured party to obtain compensation in the litigation, even though the criminal proceedings ended with the acquittal.

\section{Conclusion}

Based on the tendency, which is present in European human rights law, that in addition to the protection of the basic rights of the accused in criminal proceedings, the fundamental rights of the injured party are protected, the European Court has evolved in its jurisprudence. In the previous practice of the Court, there was a position on the restrictive application of paragraph 1 of Article 6 of the Convention to the injured party, when they are procedural subjects in criminal proceedings. The strict criteria for the existence of a "dispute" and a "decisive influence" of the outcome of the criminal proceedings on the rights of the injured party are on that track. This approach, however, proved flawed, especially when it came to legal certainty, as the Court made contradictory decisions, even in the case of petitions against the same State (that approach we could see in above mentioned cases against French). In the Perez case, the Grand Chamber of the Court noted these shortcomings and inconsistencies in the Court's case-law and decided to base the judgment on a different approach. The key criterion of the new approach of "close connection" between the criminal and civil components of the procedure, emphasizing that exceptions to the application of paragraph 1 of Article 6 must be interpreted restrictively, seems to open the door to fuller protection of victims' rights. In this way, the Court implemented its previously used principle of interpretation of the Convention as a "living instrument" and further enriched the right to a fair trial and expanded its scope and borders, except for the accused and the injured party. Under Serbian law, there is a legal possibility for the injured party to obtain compensation in litigation, although the criminal proceedings ended with the acquittal. Given that, it cannot be said that the outcome of the criminal proceedings has a decisive influence on the realization of damages in litigation, 
at least from the formal point of view. Regarding the criterion of close connection between the criminal and civil component when the injured party is found in criminal proceedings, in any capacity, we believe that it exists, given that the award of damages, as the subject of a property claim, crucially depends on determining criminal responsibility, ie. from the conviction in criminal proceedings. Accordingly, the rights contained in Article $6 \S 1$ of the Convention also belong to the injured party in the criminal proceedings. National courts as well as the Serbian Constitutional Court should pay special attention to this fact, in order to prevent possible complaints to the European Court of Human Rights, in which the injured parties would allege a violation of Article $6 \S 1$ of the Convention.

\section{References}

Carić, M, (2006) Pojam načela pravičnog postupka pred kaznenim sudom [The notion of the principle of fair procedure before the criminal court], Proceedings of the Faculty of Law in Split, 2, 55-73

Djurdjic, V, (2014), Krivično procesno pravo - opšti deo [Criminal Procedure Law - general part], Law faculty in Nis, 2014

Ilic, I, (2012), Putevi i stranputice prava na pravično suđenje[Roads and diversions of the right to a fair trial], Proceedings of the Faculty of Law in Nis, 59, 211-228

Kneževic, S, (2017), Procesno pravo - opšti deo [Criminal Procedure Law general part], Law faculty in Nis

Krapac, D, (2000), Kazneno procesno pravo, Institucije, [Criminal Procedure Law, Institutions] Faculty of Law in Zagreb

Leach, F., (2007),Obraćanje Evropskom sudu za ljudska prava, knjiga 1[Taking a case before European Court on human rights], Beograd

Mrcela, M, Bilusic, I, (2016), Konfrontacijska mjerila, Hrvatski ljetopis za kaznene znanosti i praksu[Confrontation criteria], Croatian Yearbook of Criminal Sciences and Practice, 23(2), 371-401

\section{Case Law}

Le Compte, Van Leuven and De Meyere v. Belgium, no. 6878/75 7238/75, $(23 / 06 / 1981)$

Masson and Van Zon v. the Netherlands, no. 15346/89, 15379/89 (28.09.1995)

Engel and others v. the Netherlands, app. no. 5100/71; 5101/71; 5102/71; 5354/72; 5370/72, (08/06/1976)

Ezeh and Connors v. the United Kingdom, app. nos. 39665/98 and 40086/98, $(09 / 10 / 2003)$

Tolstoy Miloslavsky v. the United Kingdom, app. no. 18139/91, (13/07/1995)

Ringeisen v. Austria, app. no 2614/65 , (16/07/1971)

Golder v. the United Kingdom, app. no. 4451/70, (21/02/1975) 
Le Compte, Van Leuven and de Meyer v. Belgium, app. no. 6878/75 7238/75, $(23 / 06 / 1981)$

Tyrer v. the United Kingdom no. 5856/72 (25/04/1978)

Benthem v. the Netherlands, app. no. 8848/80, (23/10/1985)

Weber v. Switzerland, app. no. 11034/84 , (22/05/1990)

Moreira de Azevedo v. Portugal, app. no. 11296/84, (23/10/1990)

Helmers v. Sweden, app. no. 11826/85, (29/10/1991)

Tomasi v. France, app. no. 12850/87, (27/08/1992)

Fayed v. the United Kingdom, no. 17101/90 (21.09. 1994)

Acquaviva v. France, app. no. 19248/91, (21/11/1995)

Hamer v. France, app. no. 19953/92 , (07/08/1996)

Ait-Mouhoub v. France, app. no. 22924/93, (28/10/1998)

Maini v. France, app. no. 31801/96 , (26/10/1999)

Calvelli and Ciglio v. Italy, app. no. 32967/96, (17/01/2002)

Perez v. France, app. no. 47287/99, (12/02/2004)

Roche v. the United Kingdom, app. no. 32555/96, (19/10/2005) (Grand Chamber)

Balmer-Schafrothi and Others v. Switzerland, no. 22110/93 (26/08/1997)

\section{International documents}

European Convention on the Compensation of Victims of Violent Crimes, Strasbourg 24 November 1983, European Treaties - E.T.S. 116.

$\operatorname{Rec}$ (2000) 19 on the role of the public prosecutor in the criminal justice system Recommendation no. R (85) 11 of the Committee of Ministers to member states on the position of the victim in the framework of criminal law and procedure.

Recommendation no. $R$ (87) 21 on the assistance to victims and the prevention of victimization.

Recommendation Rec(2006)8 of the Committee of Ministers to member states on assistance to crime victims

Resolution (77) 27 on the compensation of victims of crime 
